\title{
Research Paper \\ Efficacy of Gottman's marital Counseling on marital satisfaction and marital adjustment of married women willing to get divorced
}

\begin{abstract}
Citation: Padash Z, Yousefi Z, Abedi M.R, Torkan H. Efficacy of Gottman's marital Counseling on marital satisfaction and marital adjustment of married women willing to get divorced. $\mathrm{J}$ of Psychological Science. 2021; 20(104): 1423-1436.
\end{abstract}

Zahra Padash ${ }^{1}$, Zahra Yousefi ${ }^{2}$, Mohammad Reza Abedi ${ }^{3}$, Hajar Torkan $^{2}$

1. Ph.D Student Counseling, Department of Educational Sciences and Psychology, Isfahan (Khorasgan) Branch, Islamic Azad University, Isfahan, Iran.

2. Assistant Professor, Clinical Psychology group, Department of Educational Sciences and Psychology, Isfahan (Khorasgan) Branch, Islamic Azad University, Isfahan, Iran.

3. Counseling Professor, Department of Counseling, faculty of Education and Psychology, University of Isfahan, Isfahan, Iran.
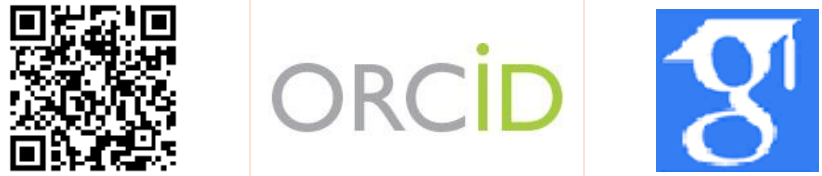

URL: https://psychologicalscience.ir/article-1-1311-fa.html

$\underline{10.52547 / J P S .20 .104 .1423}$

\section{A R T I C L E I N F O A B S T R A C T}

Keywords:

marital counseling, divorce desire, marital satisfaction, marital adjustment

Received: 28 Jun 2021

Accepted: 22 Jul 2021

Available: 23 Oct 2021
Background: Divorce tendency resulting from marital conflicts, which lead to less marital satisfaction and marital adjustment can be decreased by therapy approaches including Gottman's couple therapy.

Aims: The present study aims at investigating the effectiveness of Gottman's couple therapy on marital satisfaction and marital adjustment in married women seeking divorce.

Methods: Quasi-experimental design involving pre-test, post-test, and a control group was used to addres the purpose of the present study. All the women referring to three counselling centers in Isfahan in 2019 comprised the research population out of which 30 married women seeking divorce were selected as the research sample through convenievnce sampling method and were randomly divided into two experimental and control groups. Data were collected using couple satisfaction index (Funk \& Rogge, 2007) and dyadic adjustment scale (Spanier, 1976). The experimental group women were trained for 10 ninety-minute sessions. Both groups responded to the questionaries at pretestposttest stages. Descriptive statistics (mean and standard deviation) and inferential statistics (ANCOVA) were used to analyze data.

Results: It was revealed that Gottman's couple therapy would increase couples' satisfaction and improve marital adjustment and, in turn, the subscales of marital adjustment, i.e., satisfaction, attachment, agreement, and affection in women seeking divorce $(\mathrm{P}<0.001)$.

Conclusion: Gottman's couple therapy along with the seven research-based principles for a successful marriage proved to be an effective and efficient method to increase marital satisfaction and marital adjustment and could be used by therapists in family interventions to improve marital relationships.

* Corresponding Author: Zahra Yousefi, Proffessor, Assistant Professor, Clinical Psychology group, Department of Educational Sciences and Psychology, Isfahan (Khorasgan) Branch, Islamic Azad University, Isfahan, Iran.

E-mail: z.yousefi@khuisf.ac.ir

Tel: (+98) 9133293069

2476-5740/ (C) 2021 The Authors. This is an open access article under the CC BY-NC-ND license

(https://creativecommons.org/licenses/by-nc/4.0/). 


\section{Extended Abstract}

\section{Introduction}

Marriage is defined as one of the most foundational, sublime interpersonal bondings which satisfies and builds the personalities of its memebers (Jafari, 2018). In recent decades, researchers in the field of couple and family therapy have studied the effective mechanisms for a successful marriage. The main objective of the present study is to find the factors affecting durability of a married life. As the studies indicate, marital satisfaction and marital adjustment are important variables in predicting the stability and life duriablity among couples, which reduce the desire for divorce since they show the couples' satisfaction from their marital relationship (Azgook and Tenrivard, 2017). Marital satisfaction is defined as the subjective feelings of happiness, satisfaction, adaptability, and pleasure experienced by the couple when considering all current aspects of their marriage (Hawkins, Carrere and Gottman, 2002) and marital adjustment as the feelings of happiness and satisfaction the couples experience in their marriage (Patterson et al., 2014). While promoting marital satisfaction and adjustment would contribute to the stability of the family, marital education plays a significant role in improving this family unit. Among the models introduced to modify family units in the last decade, Gottman's couple therapy has been of great attention (Karbalaei and Azari, 2017; Gottman, Lonson, Swanson et al., 2003). Gottman developed his theory of couple therapy after 14 years of research on divorce and the causes of divorce. Gottman's theory is an integrated approach that is based on doctrinal principles of various therapeutic theories. Given the importance of developing and testing proper methods to improve positive family units, the present study, as the firs research in this regard, addressed this issue to answer the question as to whether Gottman's theory of couple therapy would affect marital satisfaction and marital adjustment in the case of the married women who seek divorce?

\section{Method}

The present research is of quasi-experimental design involving pre-test, post-test. The statistical population consisted of all the women referring to three counselling centers in Isfahan in 2019. Taking the selection criteria and ethical considerations in to account, 30 married women seeking divorce were selected as the research sample through convenievnce sampling method and were randomly divided into experimental and control group (15 people in each group).

While the experimental group was subjected to intervention, the control group received no intervention.

\section{Couples Satisfaction Index (CSI)}

This index is a 32-item measure of the marital satisfaction developed by Rogge and Funk. The marital satisfaction questionnaire has 32 statements. The Cronbach's $\alpha$ coefficient for the whole scale was reported 0.98 .

\section{DYADIC ADJUSTMENT SCALE (DAS)}

Developed by Spanier in 1976, DAS is a 32-item selfreport tool. Spanier (1976) reported its total scale reliability as 0.96 .

Data were analyzed using Descriptive statistics (mean and standard deviation) and inferential statistics (ANCOVA) performed with SPSS software (v.20).

\section{Results}

The descriptive indicators of marital satisfaction and marital adjustment and its subscales in the pre-test and post-test stages for the both experimental and control groups are presented in table 1 . The findings reveal the mean of post-tests scorse of marital satisfaction, marital adjustment, and the subscales of marital adjustment (attachment, agreement, affection, satisfaction) in the experimental group has increased in the post-intervention stage. 
Table 1. Descriptive indicators of marital satisfaction and marital adjustment variables and subscales of marital adjustment in pre-test and post-test stages for experimental and control groups

\begin{tabular}{|c|c|c|c|c|c|}
\hline Variable & Group & & Pre-test & & Post-test \\
\hline \multirow{3}{*}{ Marital Satisfaction } & & Mean & Standard Deviation & Mean & Standard Deviation \\
\hline & Experiment & 59.07 & 4.54 & 107.73 & 3.01 \\
\hline & Evidence & 65.4 & 2.8 & 64.33 & 2.92 \\
\hline \multirow{2}{*}{ Marital Adjustment } & Experiment & 59.00 & 4.52 & 99.8 & 2.46 \\
\hline & Evidence & 60.33 & 3.83 & 59.8 & 2.91 \\
\hline \multirow{2}{*}{ attachment } & Experiment & 9.73 & 1.16 & 16.2 & 0.77 \\
\hline & Evidence & 10.47 & 1.25 & 10.07 & 1.58 \\
\hline \multirow{2}{*}{ Agreement } & Experiment & 22.07 & 3.86 & 38.53 & 1.46 \\
\hline & Evidence & 21.53 & 3.34 & 22.53 & 2.64 \\
\hline \multirow{2}{*}{ affection } & Experiment & 5.07 & 1.33 & 8.67 & 0.62 \\
\hline & Evidence & 4.6 & 1.3 & 4.33 & 0.72 \\
\hline \multirow{2}{*}{ Satisfaction } & Experiment & 22.13 & 2.64 & 36.4 & 1.3 \\
\hline & Evidence & 23.73 & 2.15 & 22.87 & 2.00 \\
\hline
\end{tabular}

ANCOVA was used to determine the significance of these differences.

Table 2. ANCOVA of marital satisfaction and marital adjustment scores and marital adjustment subscales in the experimental and control groups in the post-test

\begin{tabular}{ccccccc}
\hline The dependent variables & Df & MS & F & The significance level & Impact size & Exponentiation \\
\hline Marital Satisfaction & 1 & 8972.77 & 1.28 & 0.00 & 0.97 & 1 \\
Marital compatibility & 1 & 12042.35 & 3.25 & 0.00 & 0.99 & 1 \\
Correlation & 1 & 254.32 & 167.75 & 0.000 & 0.87 & 1 \\
the agreement & 1 & 1486.81 & 611.44 & 0.00 & 0.96 & 1 \\
Expression of love & 1 & 109.18 & 351.2 & 0.00 & 0.93 & 1 \\
Satisfaction & 1 & 1160.9 & 536.70 & 0.00 & 0.95 & 1 \\
\hline
\end{tabular}

As seen in Table 3, given the increase in marital satisfaction and marital adjustment in the experimental group in the post-test stage, the results of ANCOVA show that by removing the effect of the pretest, Gottman's couple therapy is effective on marital satisfaction, marital adjustment, and the subscales of marital adjustment, i.e., attachment, agreement, affection, satisfaction ( $\mathrm{p}<0.001)$.

\section{Conclusion}

The aim of the present study was to investigate the effectiveness of Gottman's couple therapy on marital satisfaction and marital adjustment of women seeking divorce. To explain the effectiveness of Gottman's couple therapy on the increase of marital satisfaction, it can be stated that Gottman's couple therapy stresses coping with the negative aspects of marriage and places a lot of emphasis on love and respect. Indeed, this method helps the couples have a more positive perspective of each other by emphasizing the positive aspects such as appreciation, empathy, and acceptance (Gottman \& Gottman, 2016). To discuss the effectiveness of Gottman's couple therapy on marital adjustment, addressed by Halford et al., it can be said that Gottman's approach is an integrated cognitive-systemic approach that mainly focuses on cognitive issues and the relationship between the couples. Therefore, in this approach, by eliminating and modifying incompatible cognitions and strengthening reinforcing cognitions, the relationship between the couples will be improved. Overall, given that Gottman's couple therapy is an effective approach in increasing marital satisfaction and marital adjustment of the married women seeking divorce, family counselors and therapists would be 
able to use the findings of the present study for clinical and educational interventions.

\section{Ethical Considerations}

Compliance with ethical guidelines: This article is taken from the doctoral dissertation of the first author in the field of Counseling in the Faculty of Psychology and Counseling, Islamic Azad University, Khorasgan Branch with ethical code of IR.IAU.KHUISF.REC.264.1397 and the proposal approval date of 2018.01.15.
Funding: This research is in the form of a doctoral dissertation without financial support.

Authors' contribution: The first author is the main researcher of this research. The second and third authors are the supervisors and the fourth author is the advisor of the dissertation.

Conflict of interest: The authors do not disclose any conflict of interest in relation to this research.

Acknowledgments: We would like to thank the supervisors and consultants and all the couples who cooperated with the researchers. 
اثربخشى مشاوره زناشويى به روش كاتمن بر رضايت زناشويى و ساز كارى زناشويى زنان متأهل متمايل به طلاق

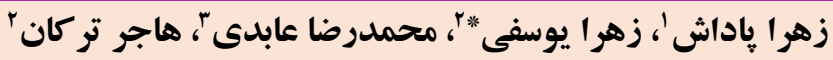

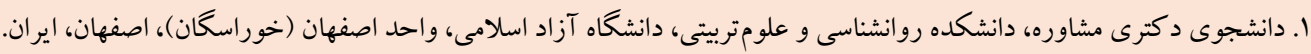

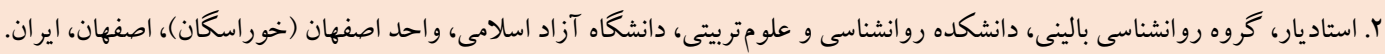
r. استاد، گُروه مشاوره، دانشكده علومتربيتى و روانشناسى، دانشگاه اصفهان، اصفهان، ايران.

\begin{tabular}{|c|c|}
\hline جكيده & مشخصات مقاله \\
\hline زمينه: ميل به طلاق در بين زنان متأهل مى تواند ناشى از تعارضات زناشويى و در نتيجه كاهش رضايت و ساز گارى زناشويى باشد كه & كليدوازهها: \\
\hline 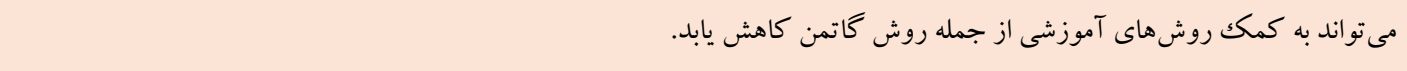 & 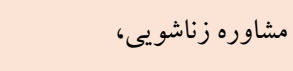 \\
\hline هدف: هدف يُوهش حاضر تعيين تأثير مشاورة زناشويى به روش كاتمن بر رضايت زناشويى و ساز كارى زناشويى زنان متأهل مايل به & 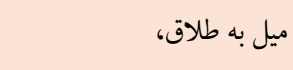 \\
\hline 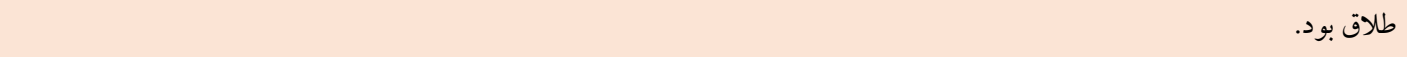 & 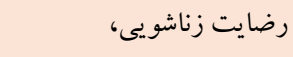 \\
\hline روش: روش يُزوهش شبه تجربى از نوع ييش آزمون، يس آزمون با كروه كواه بود. جامعه يُووهش شامل كليه زنان مراجعه كنده به سه مركز & ساز كارى زناشويى (ازي \\
\hline 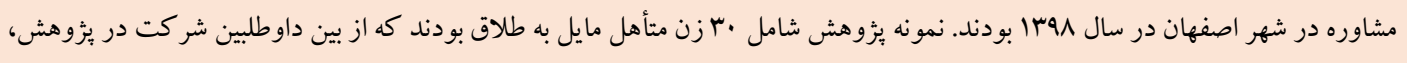 & \\
\hline به روش نمونه گيرى در دسترس انتخاب شدند و به صورت تصادفى در دو گروه آزمايش و كنترل جايكزين شدند. دادهها با استفاده از & \\
\hline 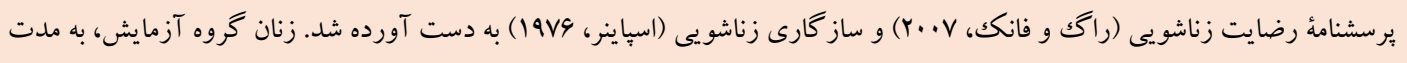 & \\
\hline •ا جلسه .9 دقيقهاى تحت آموزش قرار كرفتند. هر دو گروه در دو مرحله بيش آزمون، يِ آزمون به يرسشنامهاى يُوهش باسخ دادند. & \\
\hline دادهها با استفاده از آمار توصيفى (ميانگين و انحر اف استاندارد) و آمار استنباطى (تحليل كوواريانس) انجام شد. & \\
\hline يافته ها: يافتها حاكى از آن بود كه مشاوره زناشويى به روش گاتمن مى تواند موجب افزايش رضايت زناشويى و ساز كارى زناشويى و & \\
\hline 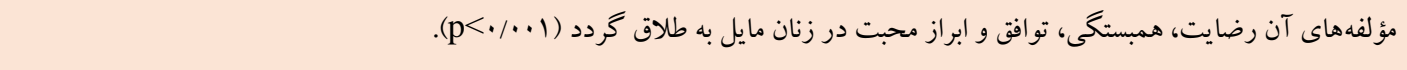 & \\
\hline نتيجه كيرى: در مجموع نتايج مطالعه حاضر نشان داد مشاوره زناشويى به روش كاتمن به كمكك آموزش هفت اصل موفقيت زوجى و فنون & 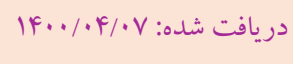 \\
\hline دستابى به آن، روشى مؤثر و كار آمد در افزايش رضايت زناشويى و ساز كارى زناشويى است و مى تواند توسط درمانكران در مداخلات & 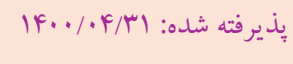 \\
\hline خانواده استفاده گردد و در نتيجه به بهبود روابط زناشويى كمكك نمايد. & 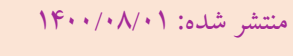 \\
\hline
\end{tabular}

* نويسنده مسئول: زهر يوسفى، استاديار، گروه روانشناسى بالينى، دانشكده روانشناسى و علومتريتى، دانشكاه آزاد اسلامى، واحد اصفهان (خوراسكان)، اصفهان، ايران. رايانامه: z.yousefi@ khuisf.ac.ir 
خوشبختى و رضايت از همديخر دارند (يترسون و همكاران، F| (Y). در

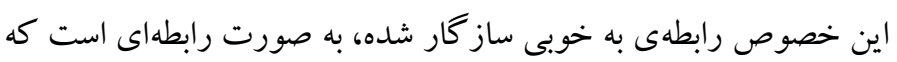

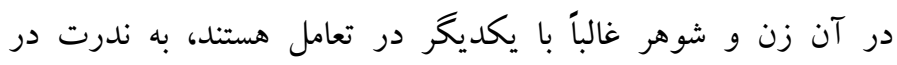

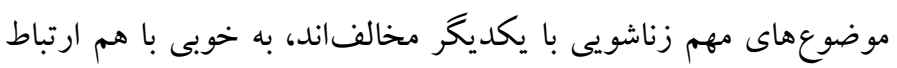

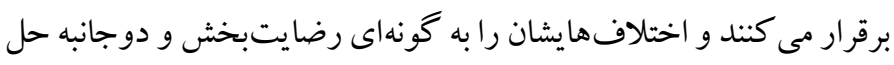
و فصل مى كنند. ساز گارى زناشويى مستلزم بلوغى است كه رشد و انطباق با آن در رابطه زوجى دركك مى شود. اكر اين رشد، كامل دركك و تجربه

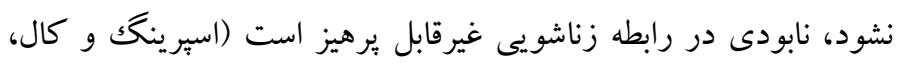

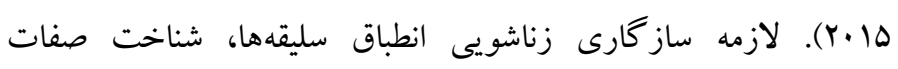
شخصيتى، ايجاد قواعد رفتارى و شكل گيرى الكوهاى ارتباطى سازنده

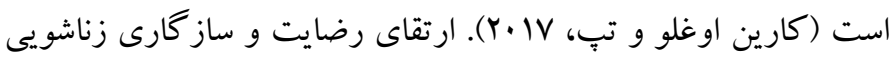

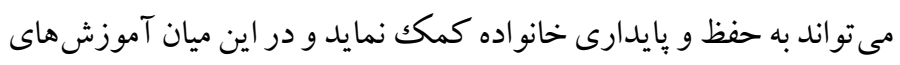

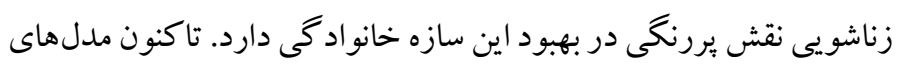

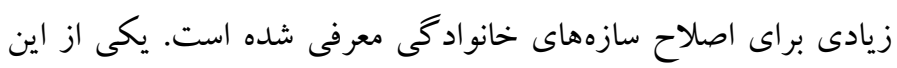

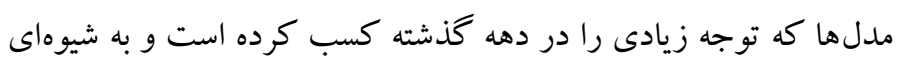

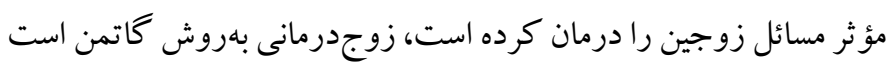

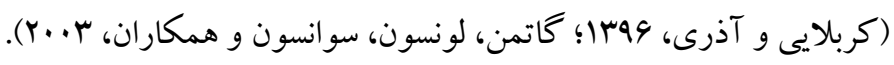

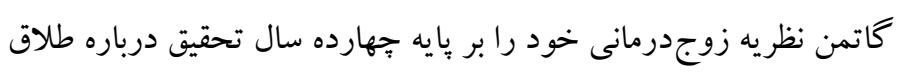

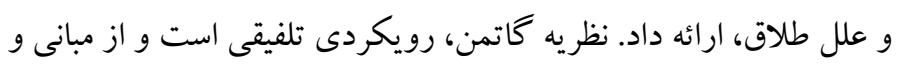
اصول اعتقادى نظريههاى مختلف درمانى يارى گرفته است. گاتمن به

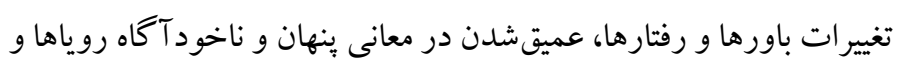
نغاه سيستمى به خانواده بهطور همزمان توجه مى كند (كاتمن و كاتمن،

.$(Y \cdot 19$

كاتمن براساس تحقيقات خود نشان دادند كه رابطهاى شاد و موفق است كه در آن زوجها با يكديخر همجون يككدوست رفتار مى كنند و تعارضات

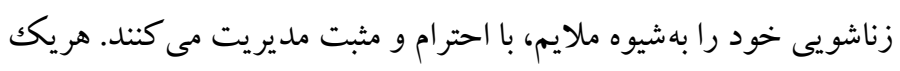

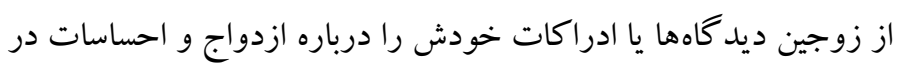

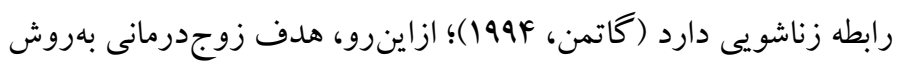
كاتمن بازسازى رابطه و تقويت رضايت زناشويى است تا به اين وسيله، به دوانه

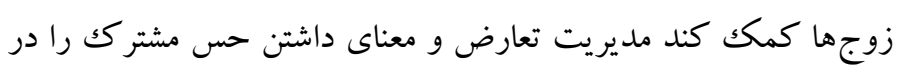

${ }^{3}$. marital adjustment dola

ازدواج يكى از قديمىترين، مهمترين و عالى ترين بيوندهاى بين فردى

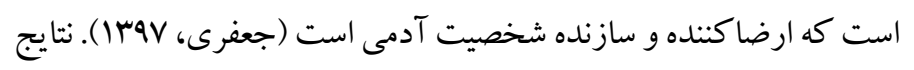
تحقيقات متعددى كه در مورد ازدواج و روابط زوجى انجام شده بر اهميت

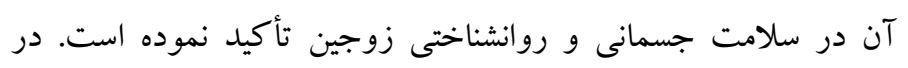

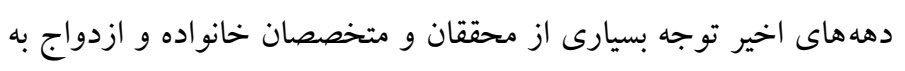

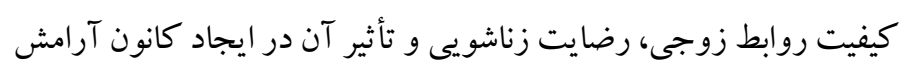

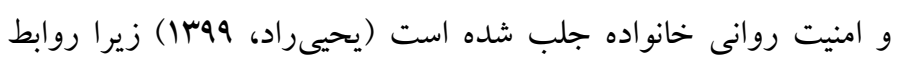

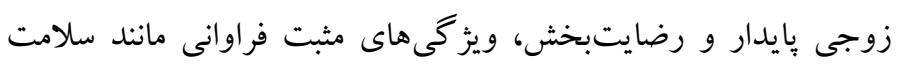

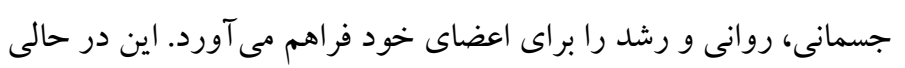

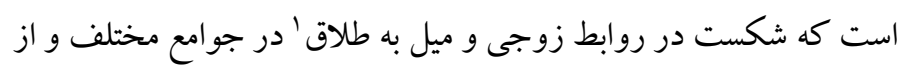

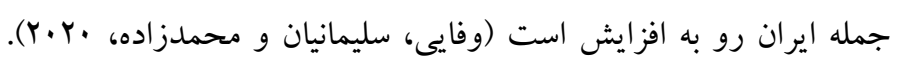
شكست در زندگى زوجى، آسيبهاى عاطفى، روانى واجتماعى عميق

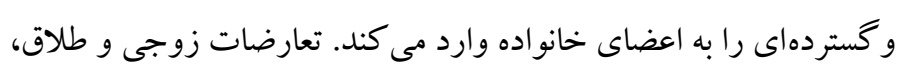

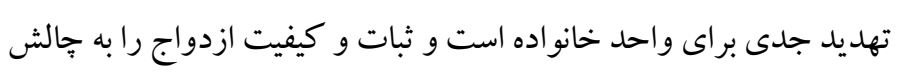
مى كشاند و باعث بروز ييامدهاى منفى همجيون اضطر اب، افسردكى، بهره

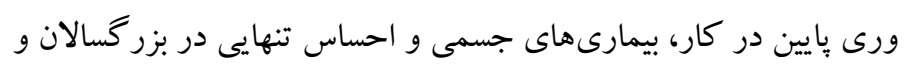

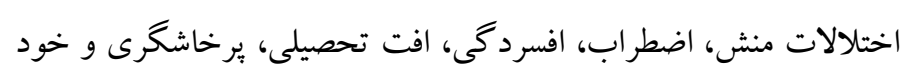

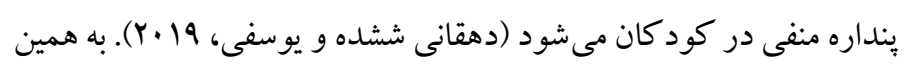

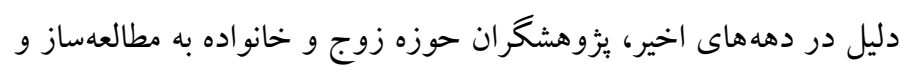

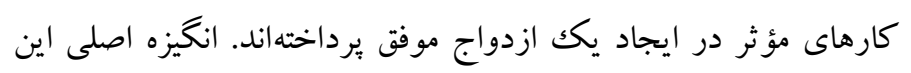

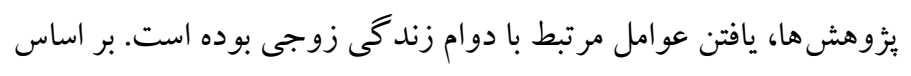

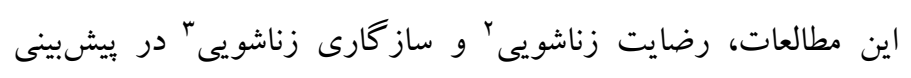

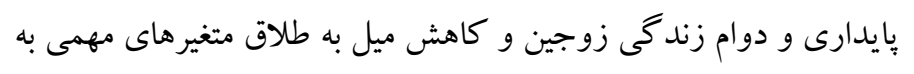

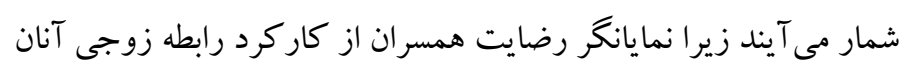

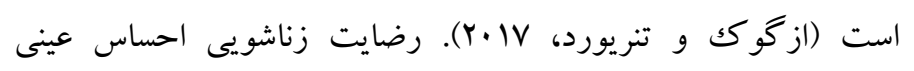

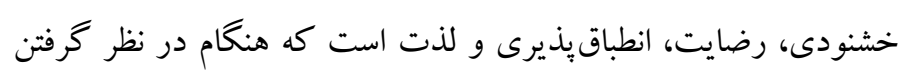
تمام ابعاد جارى زندگى زناشويى و سود و زيانهاى آن توسط فرد متأهل

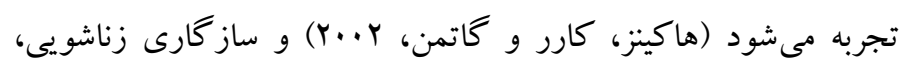
وضعيتى است كه در آن زن و شوهر در بيشتر مواقع احساس ناشى از

1. Desire to divorce

${ }^{2}$. marital satisfaction 


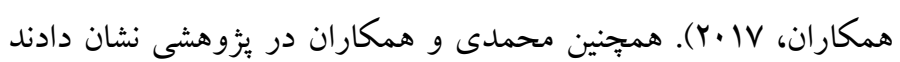

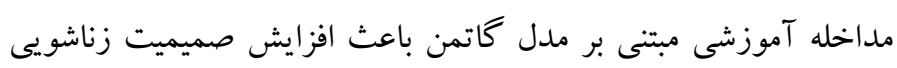

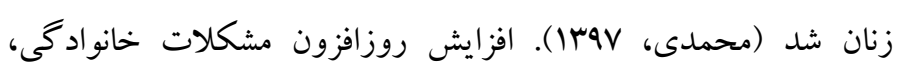
نارضايتى و ناساز گارى زناشويى، افزايش آمار طلاق و ويامدهاى سوء آن اهميت و ضرورت توجه به موضوع روابط زوجى و كاهش مشكلات آنان

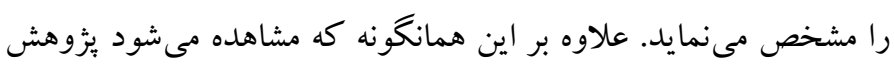

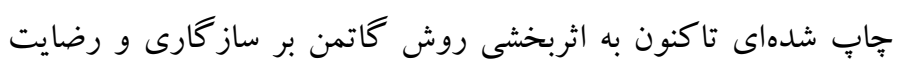

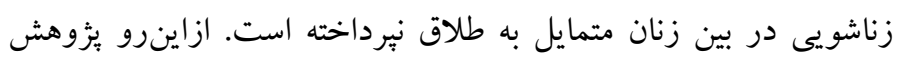

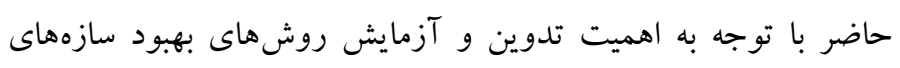
خانوادكى مثبت و از سوى ديخر نبود جنين بزؤهشى به اين مهم برداخت.

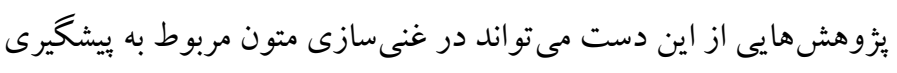

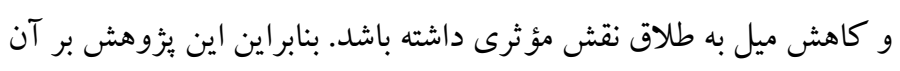

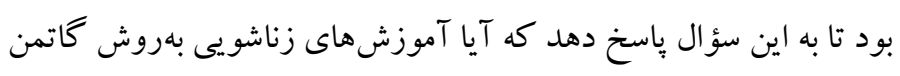
بر رضايت زناشويى و ساز كارى زناشويى زنان متأهل مايل به طلاق تأثير

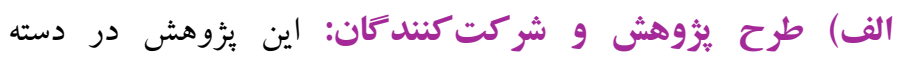

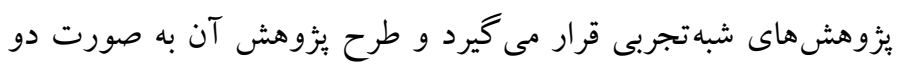

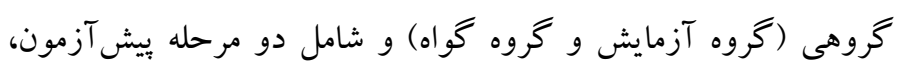
بس آزمون بود. جامعه آمارى آن شامل كليه زنان متأهل مايل به طلاق

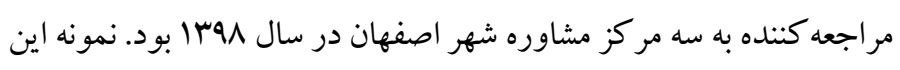

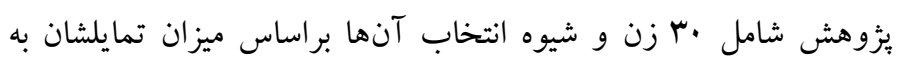

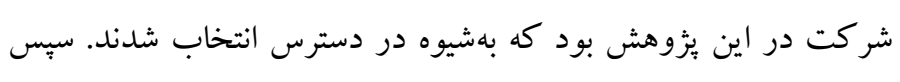

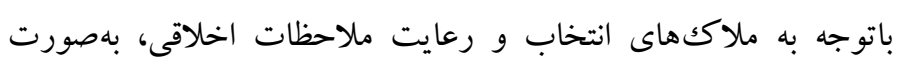

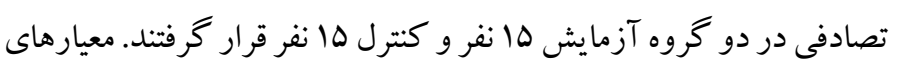

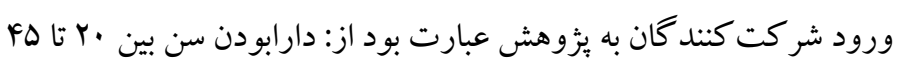
سال؛ داشتن حداقل يكك سال زندگى مشتر ك؛ كسب نمره كمتر از نقطه برش ميل به طلاق (نمره بيشتر از FF). شرايط خروج: ا. عدم مايل به ادامه

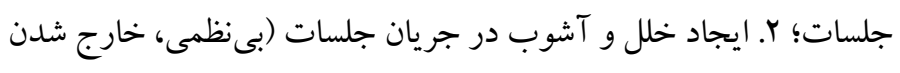
از موضوع اصلى). ملاحظات اخلاقى شامل ارائه اطلاعاتى كتبى درباره
رابطه بياموزند. طبق نظر كاتمن، وجود جهار عامل تخريب كننده درروابط زوجى با و1 درصد اطمينان، بيشبينى كننده طلاق است. اين جهار عامل عبار تند از: انتقاد؛ سرزنش؛ جبهه گيرى؛ سكوت. گاتمن و همكاران اظهار

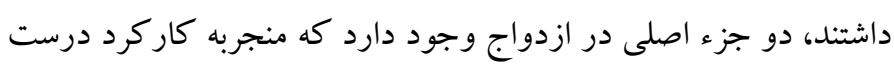

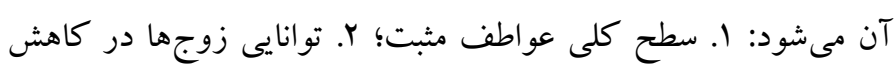

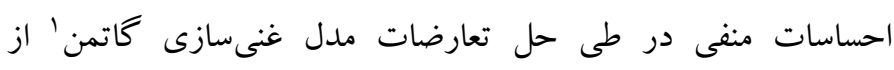

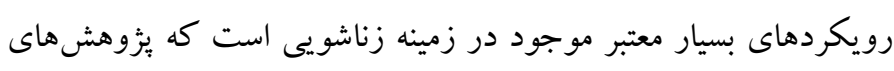

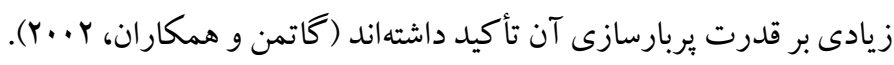

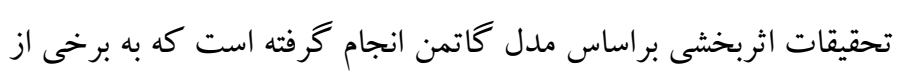

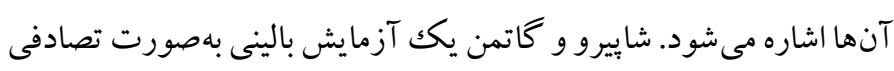

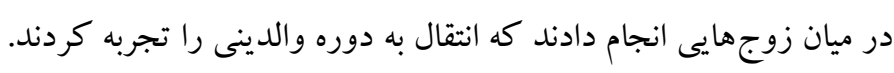

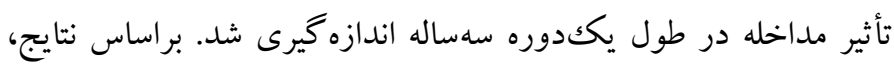

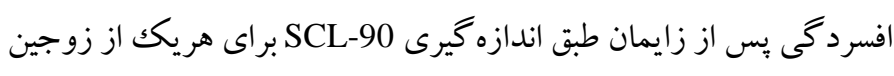

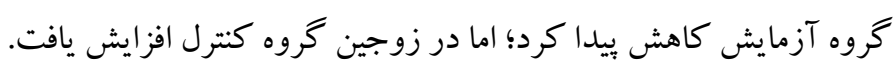
يرخاشخرى زناشويى در طى يكك سال براى هريك از زوجين گرُوه مداخله

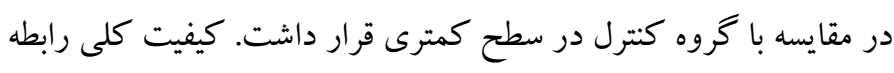

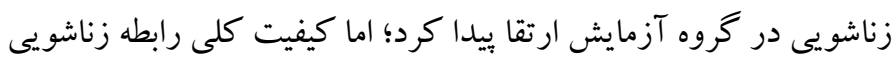

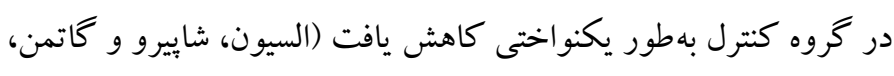

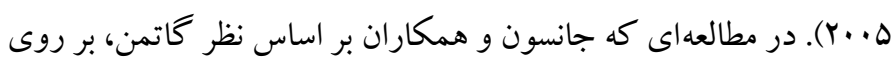
تفاوتهاى رفتارى زوجهاى يريشان و عادى انجام دادند، نتايج نشان داد هاد

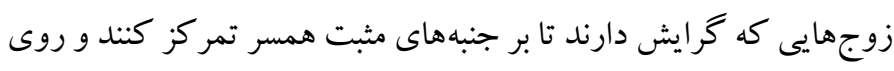

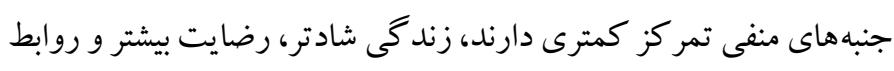

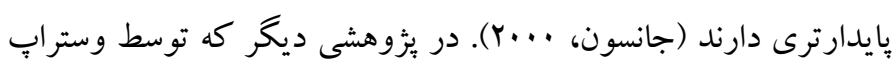

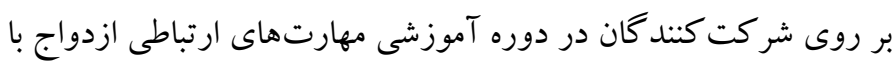

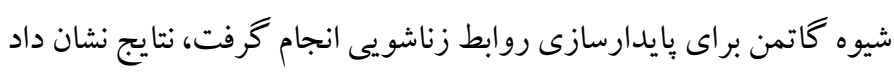

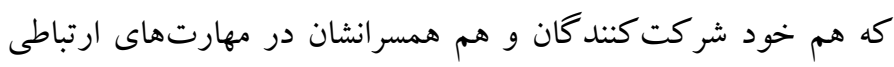

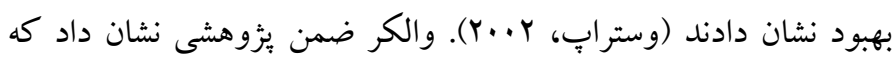

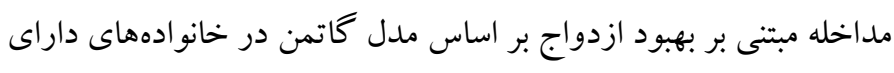

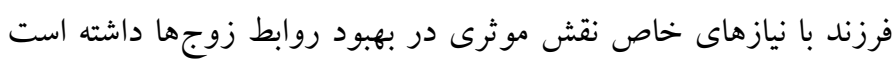

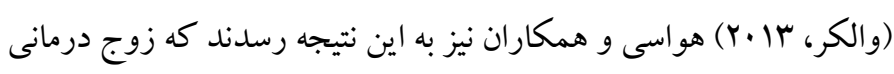

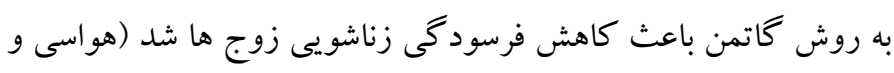

${ }^{1}$. Gottman's enrichment model 
مجموع سؤالات بين صفر تا اها است. نمرات بالاتر نشان دهنده رابطه بهتر است. براى افزايش اطمينان مقياس، تعدادى از سؤالات به صورت مثبت و تعدادى به صورت منفى طراحى شده است. بنابراين برخى از سؤالات مستلزم معكوس كردن جهت نمره گذارى است. از نظر اسياينر افرادى كه نمره آنها 1 • ا يا كمتر از آن باشد، مشكلدار و ناساز كار محسوب شده و افراد داراى نمرات بالاتر از 1 •. ساز كار به حساب مى آيند. ميانگين نمرات

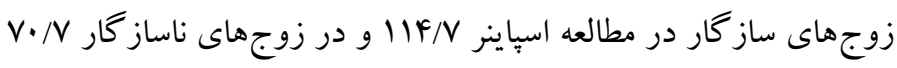
بود. اسڤاينر (9V9) اعتبار اين مقياس رادر كل نمرات 99٪\% بر آورد كرده است كه نشان مىدهد اين مقياس از همسانى درونى بالايى برخوردار است. او همسانى درونى خرده مقياسها را نيز بين خوب تا عالى بر آورده كرده است كه عبارتند از: رضايت دو نفره: \&9 درصد، همبستكى دو نفره: 11 درصد، توافق دو نفره: •9 درصد، ابزار محبت: سل درصد (اسياينر، I9V9). دانش و همكاران اين مقياس را با روش باز آزمايى و با فاصله زمانى · ل روز در نمونهاى متشكل از · rا نفر از زوج ها اجرا كرد و براى بررسى ميزان همبستخى نمر ات از روش كشتاورى ييرسون استفاده شد، ضريب همبستخى بين زنان و شوهران طى دوبار اجرا در كل نمرات \$4/ •، مقياس فرعى اول

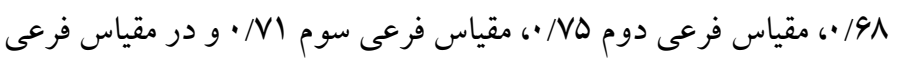

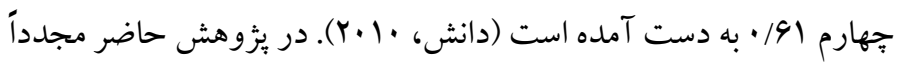
همسانى درونى اين يرسشنامه و ابعاد آن از طريق آلفاى كرونباخ محاسبه شد و بالاتر از V/ • به دست آمد. از IR.IAU.KHUISF.REC. 1397raץ إن بس از اخذ شناسه اخلاق كميته اخلاق و انتخاب نمونه، مداخله آزمايشى، يعنى مشاوره زناشويى

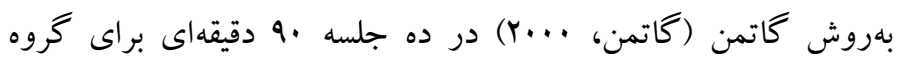
آزمايش اجرا شد. شركت كنند گان گروه گواه هيج گونه مداخله درمانى دريافت نكردندو به روال عادى خود ادامه دادند. ييش از انجام مداخله آزمايشى بيش آزمون و يس از اتمام جلسات، بِ آزمون ازهر دو گروه به عمل آمد. بعد از كردآورى اطلاعات دادههاى جمع آورى شده با استفاده از آمار توصيفى، ميانكين، انحراف معيار و آمار استنباطى با روش تحليل كوواريانس، به كمك نرمافزار SPSS.20 تحليل دادهها صورت كرفت. در تمامى آزمونها سطح معنادارى برابر با هـ/ • در نظر گرفته شد. خلاصه
يثزوهش به شركت كنند گان، دادن اطمينان خاطر به افراد درباره رعايت

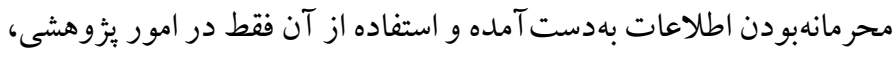

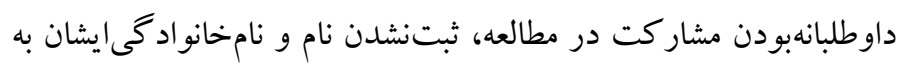
منظور رعايت حريم خصوصى و دريافت رضايت كتبى از شركت كنند كان

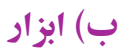
شاخص رضايت زناشويى (CSI)': شاخص رضايت زناشويى توسط راكى

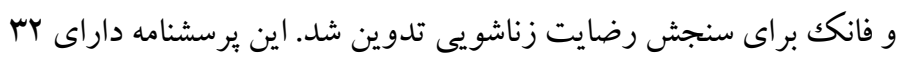
كزاره است كه با طيف ليكرت شش درجهاى تنظيم شده است. تنها گزاره

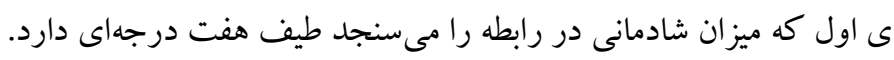

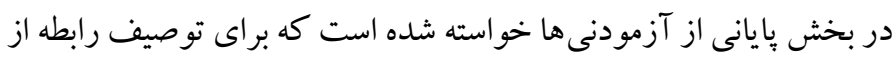

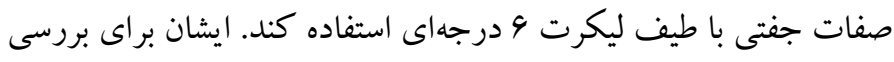

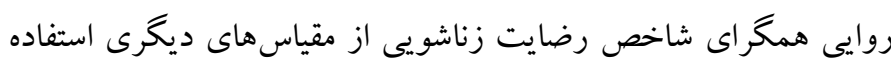

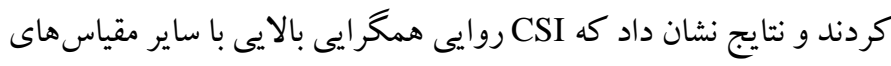

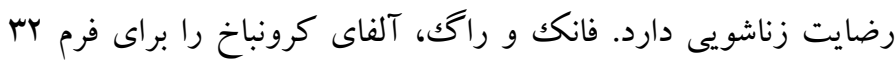

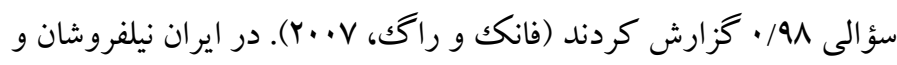

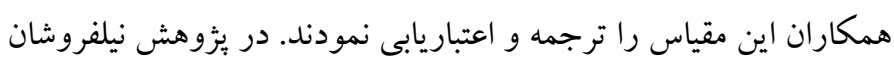

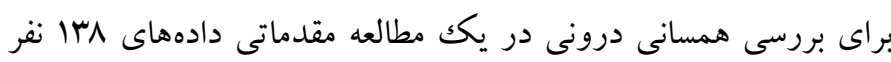

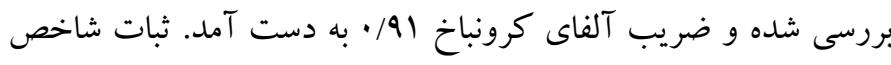

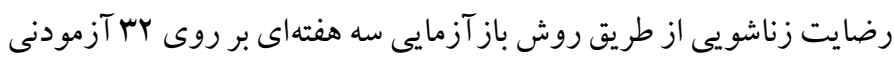

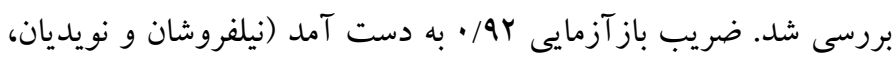

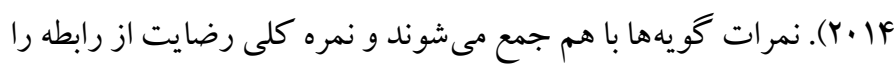

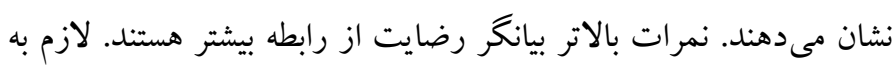
ذكر است در بثزوهش حاضر مجدداً همسانى درونى اين برسشنامه و ابعاد

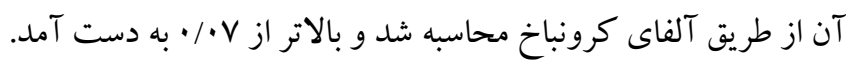

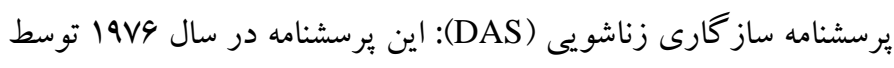

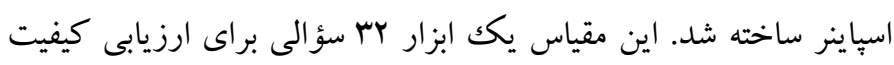

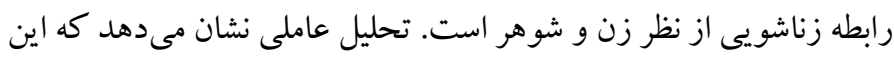

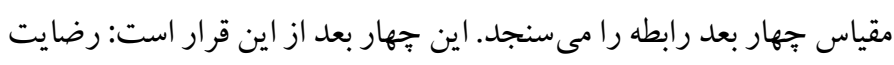

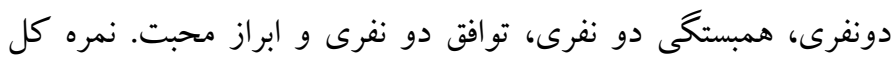

${ }^{1}$. Couples satisfaction index 
محتواى جلسات مشاوره زناشويى به روش كاتمن در جدول ا ارائه شده

جدول ا. محتواى آموزشى جلسات بهروش كاتمن

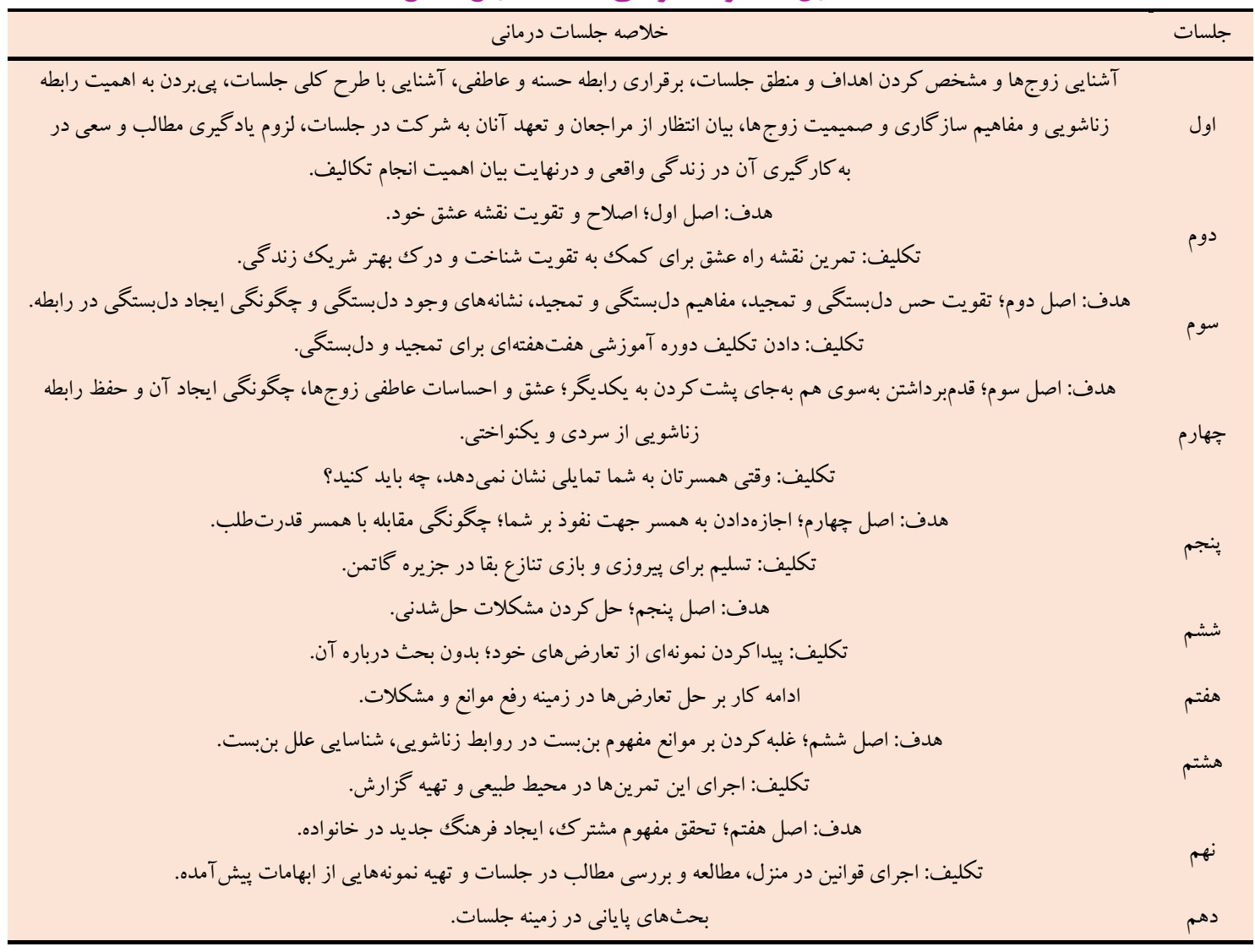

براى تعيين معنادارى اين تفاوتها باتوجه به اينكه لازم است بيش آزمون

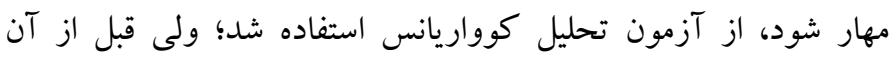

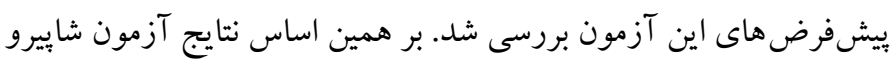

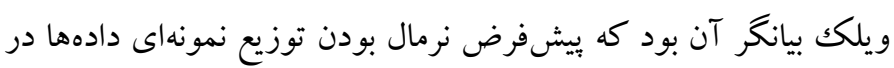
متغير مورد مطالعه در زنان متمايل به طلاق در مراحل ييش آزمون

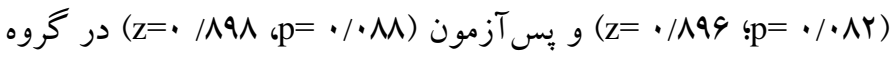
آزمايش و گ گاه برقرار بوده است. همخنى واريانس ها توسط آزمون لوين

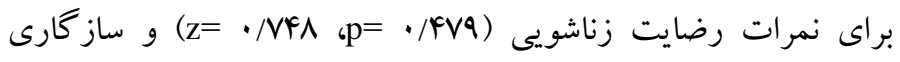

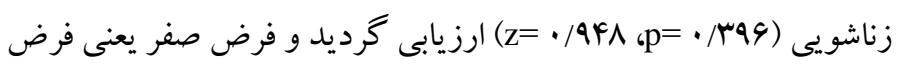

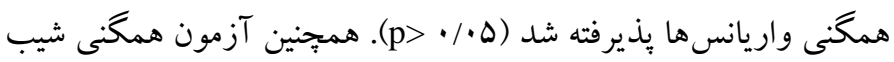

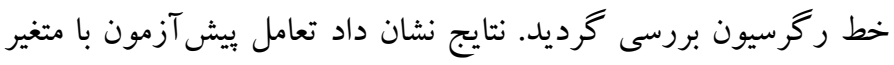

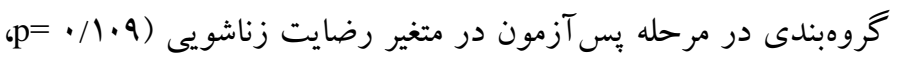

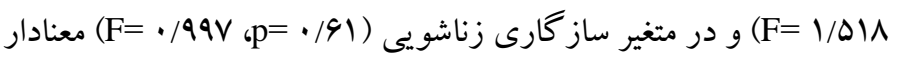

يافته ها ميانگين گروه سن گروه آزمايش

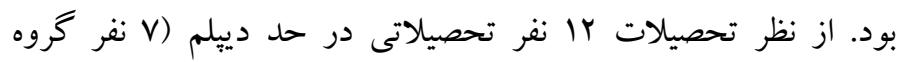

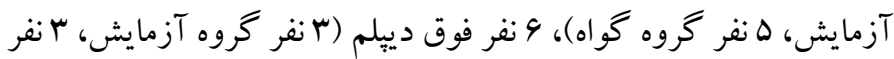

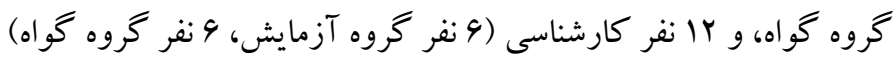

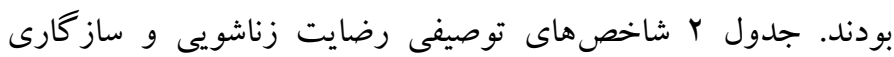

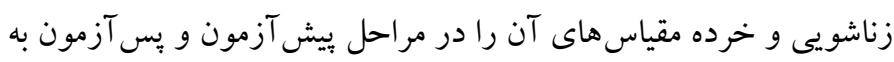

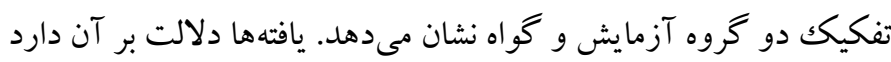

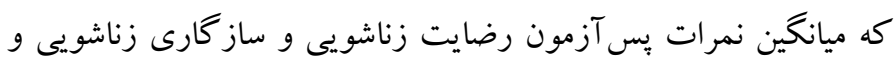
خرده مقياسهاى ساز گارى زناشويى (همبستگى، توافق، ابراز محبت،

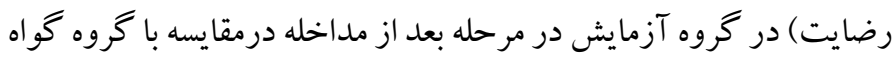
افزايش يافته است. 
نبوده است. اين بدان معناست كه فرض همخنى شيب خط ركرسيون در كوواريانس براى آزمون فرضيههاى تحقيق به كار رفت.

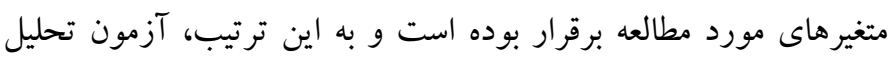

جدول ז. شاخصهاى توصيفى متغيرهاى رضايت زناشويى و ساز كارى زناشويى و خرده مقياسهاى ساز كارى زناشويى در مراحل ييش آزمون و يسآزمون بهتفكيك دو كروه

\begin{tabular}{|c|c|c|c|c|c|}
\hline \multicolumn{2}{|c|}{ يس آزمون } & \multicolumn{2}{|c|}{ ييش آزمون } & \multirow{2}{*}{ كروه } & \multirow{2}{*}{ متغير } \\
\hline انحر اف معيار & ميانكين & انحر اف معيار & ميانگين & & \\
\hline$r / .1$ & $1 \cdot V / N r$ & $F / \Delta F$ & $\Delta q / \cdot V$ & آزمايش & \multirow{2}{*}{ رضايت زناشويى } \\
\hline r/AY & $G 4 / M$ & $r / \Lambda$ & $90 / 4$ & كواه & \\
\hline r/FG & $৭ ৭ / \wedge$ & $r / \Delta r$ & $\Delta q / \cdot \cdot$ & آزمايش & \multirow{2}{*}{ ساز كارى زناشويى } \\
\hline$r / 91$ & $\Delta Q / \Lambda$ & r/A & 9./r & كواه & \\
\hline$\cdot M V$ & $19 / r$ & $1 / 19$ & $9 / v r$ & آزمايش & \multirow{2}{*}{ همبستكى } \\
\hline $1 / \Delta \Lambda$ & $1 \cdot 1 \cdot v$ & $1 / r \Delta$ & $1 . / 4 V$ & كواه & \\
\hline $1 / 49$ & rN/DT & r/A9 & $Y Y / \cdot V$ & آزمايش & \multirow{2}{*}{ توافق } \\
\hline$r / 94$ & $r r / \Delta r$ & $r / \mu F$ & $r M / \Delta r$ & كواه & \\
\hline .194 & $\Lambda / 9 V$ & $1 / \pi r$ & $\Delta / \cdot V$ & آزمايش & \multirow{2}{*}{ ابراز محبت } \\
\hline$\cdot / V r$ & F/R & $1 / r$ & $F / 9$ & كواه & \\
\hline $1 / r$ & $r q / F$ & $r / 94$ & $r Y / I r$ & آزمايش & \multirow{2}{*}{ رضايت } \\
\hline$r / \cdot \cdot$ & Yr/AV & $r / 1 \Delta$ & $r r / v r$ & كواه & \\
\hline
\end{tabular}

جدول م. نتايج تحليل كواريانس نمرات رضايت زناشويى و ساز تارى زناشويى و خرده مقياسهاى سازتارى زناشويى در دو تروه آزمايش و تواه در يس آزمون

\begin{tabular}{|c|c|c|c|c|c|c|}
\hline توان & اندازه تأثير & سطح معنى دارى & $\mathrm{F}$ & MS & Df & متغير هاى وابسته \\
\hline 1 & $\cdot / 9 \mathrm{~V}$ & $\cdot / \cdot$ & $1 / Y \wedge$ & $\Lambda q \vee Y / V V$ & 1 & رضايت زناشويى \\
\hline 1 &.$/ 99$ &.$/$ & $r / r \Delta$ & $I T \cdot F Y / F \Delta$ & 1 & ساز كارى زناشويى \\
\hline 1 & $\cdot / \mathrm{AV}$ & $\cdot \ldots$ & $19 \mathrm{~V} / \mathrm{VD}$ & $r \Delta F / R Y$ & 1 & بستكى \\
\hline 1 &.$/ 99$ &.$/ \cdot$ & $911 / 4 F$ & $|F \wedge 9 / \wedge|$ & 1 & تو افق \\
\hline 1 & . & $\cdot / \cdot$ & $r \Delta / / r$ & $1.9 / 11$ & 1 & ابراز محبت \\
\hline 1 &.$/ 90$ &.$/$ & $\Delta r G / v$. & $119 \cdot / 9$ & 1 & رضايت \\
\hline
\end{tabular}

يكك آسيب اجتماعى در نظر گرفته شده است. در سبب شناسى عوامل

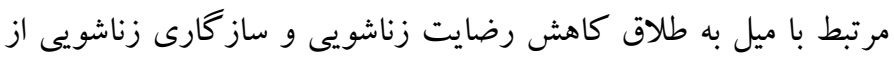

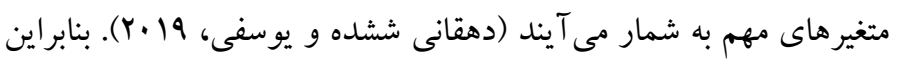

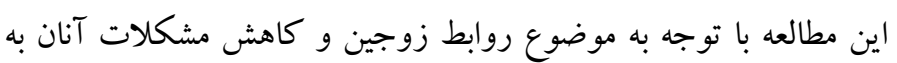

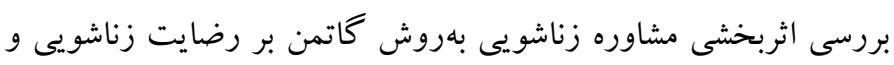

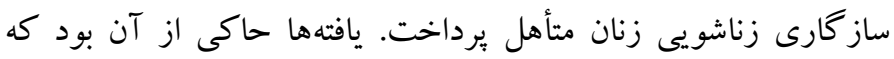

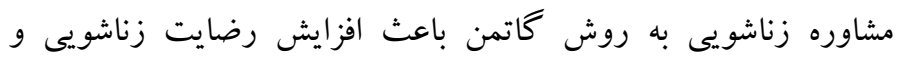

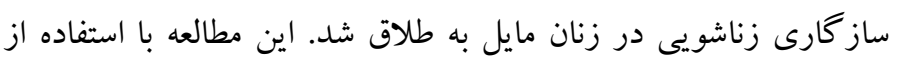

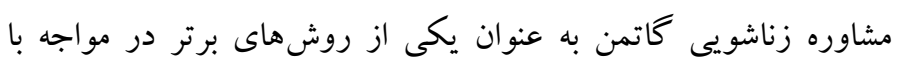

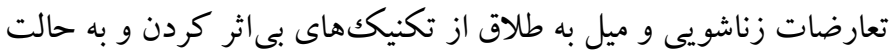

همانطوركه در جدول r مشاهده مىشود باتوجه به افزايش رضايت زناشويى و ساز گارى زناشويى در گروه آزمايش در مرحله بـ بس آزمون،

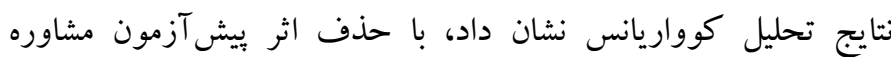
زناشويى بهروش كاتمن بر رضايت زناشويى و ساز گارى زناشويى و خرده

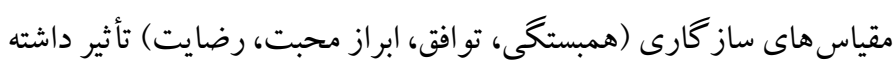

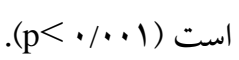

بحث و نتيجه كيرى طلاق مهم ترين شاخصه آشفتكى روابط زوجى و نشاندهنده آسيب عميق

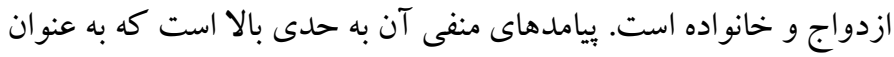


بهبود روابط متقابل به همسران كمك مى كند تا در هنگام حل تعارضات زناشويى توانايى كاهش عاطفه منفى را داشته باشند.

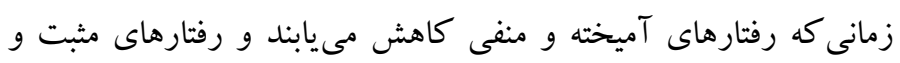

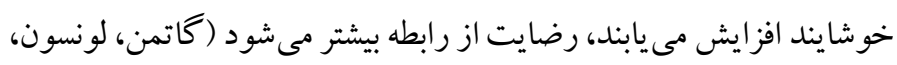

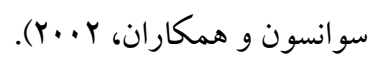

در تبين اثربخشى مشاوره زناشويى بر ساز گارى زناشويى بر مبناى نظر

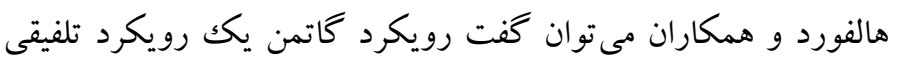

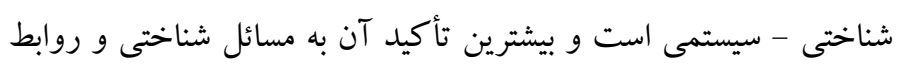

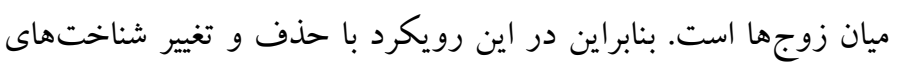
ناساز كار و تقويت شناخت هاى تقويت كننده، روابط خوشايند ميان زوجها را بهبود مىبخشد. اين رويكرد همجنين از طريق بهبود روابط كلامى و

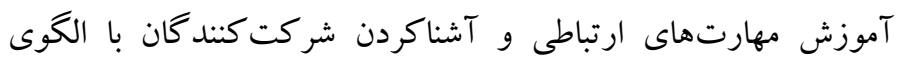

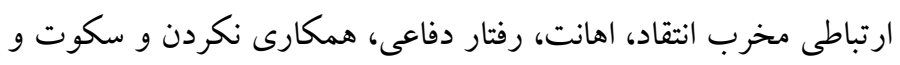

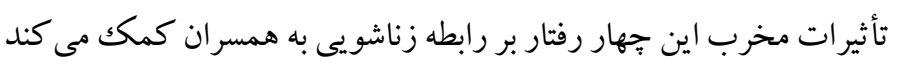

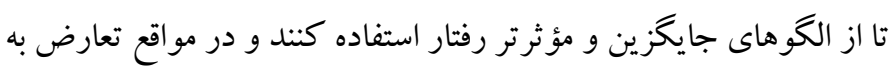

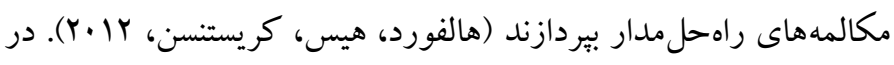
نتيجه مشاوره زناشويى به روش كاتمن با تقويت تعهد و افزايش روابط ريط

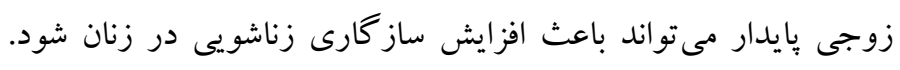

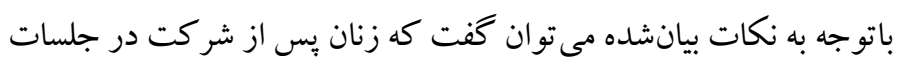

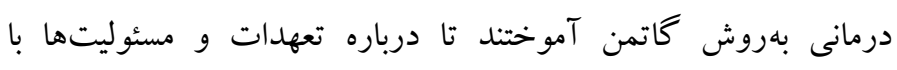

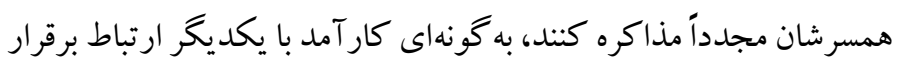

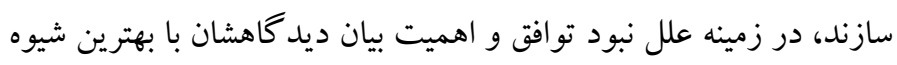

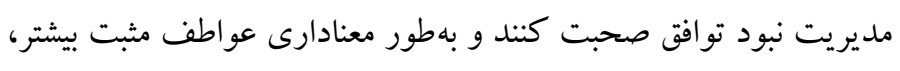

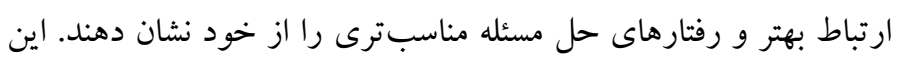

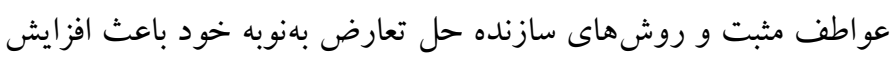

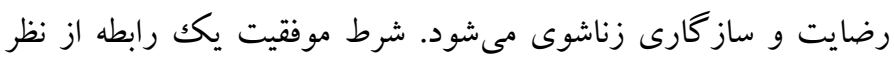
كاتمن، سطح كلى عواطف مثبت و توانايى كاهش عاطفه منفى در هنگام حل تعارضات است. زمانى كه رفتارهاى آشفته كاهش مئ يابند و رفتارهاى مثبت و خوشايند افزايش مى يابند، رضايت از رابطه بالاتر مىرود (كاتمن

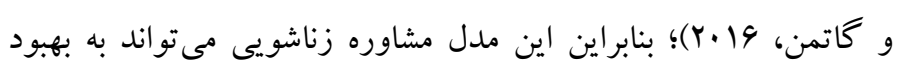
روابط در زوجين كمك كند.
محبت آميز در آوردن ارتباطات كلامى تعارض آميز، رفع مو انعى كه ايجاد احساس ماندن و ركود در موقيت هاى تعارض آميز دارد، افزايش صميميت، احترام و عاطفه و ايجاد حس همدلى و دركك بيشتر در بافت رابطهى

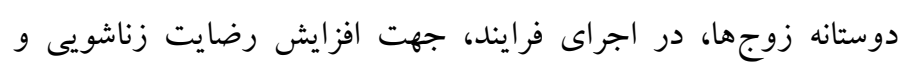

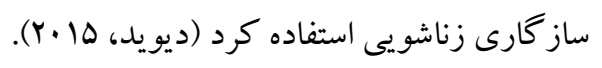
يافتهاى يزوهش حاضر همسان است با تحقيقات قبلى مثل؛ تحقيق

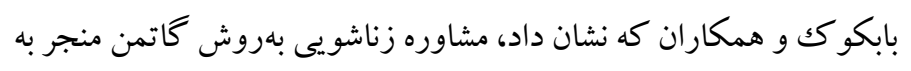
افزايش رضايت زناشويى، كاهش مشكلات زناشويى و تعارض مخرب

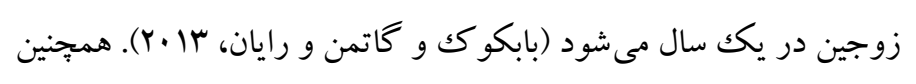
و الكر در بثزوهش خود عنوان كرد، برنامه تقويتى ازدواج گاتمن بر رضايت

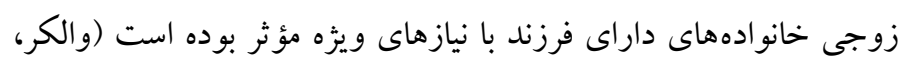

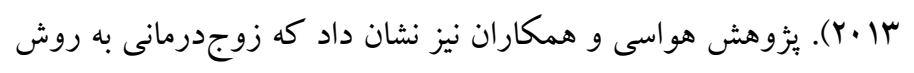
كاتمن بر كاهش فرسودگى زناشويى سودمند مىباشد (هواسى، زهراكار،

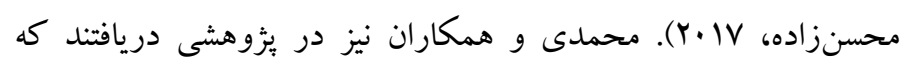

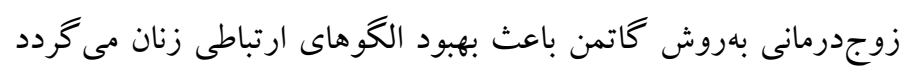

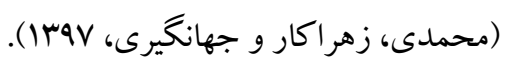

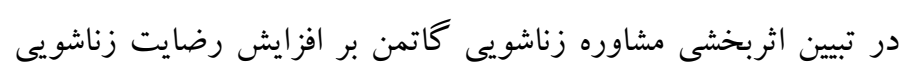

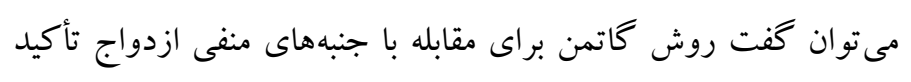
زيادى بر عشق و احترام مى كند و براى افزايش جنبه هاى مثبت با تأكيد

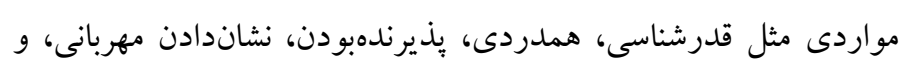

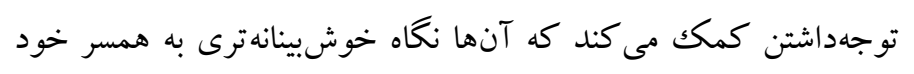

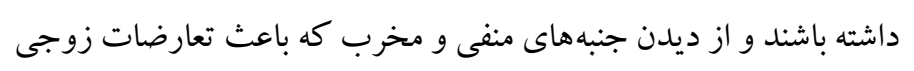

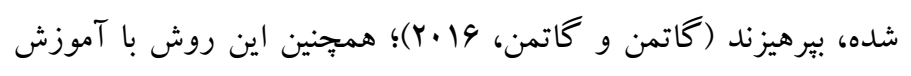

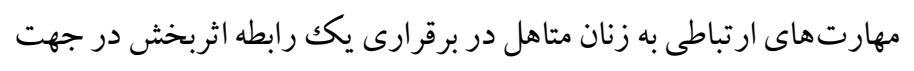

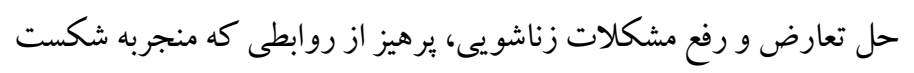

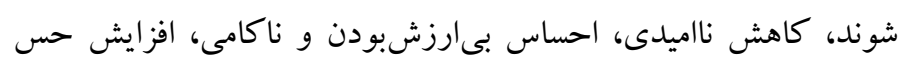

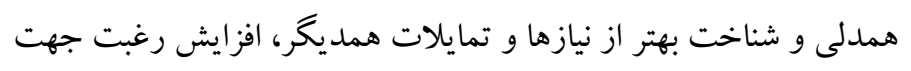

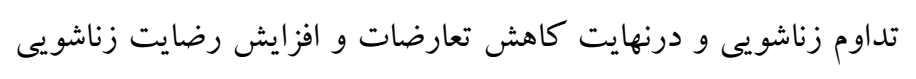

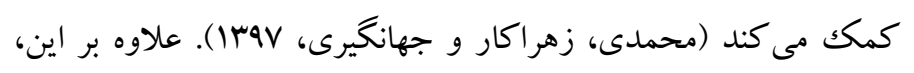

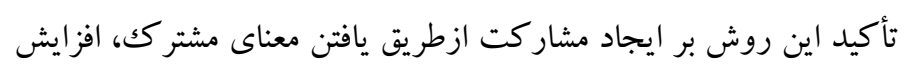

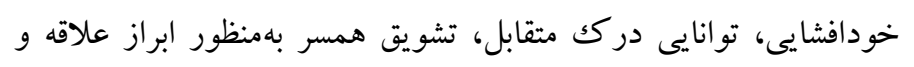




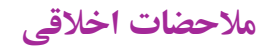

بيروى از اصول اخلاق ئوهش: اين مقاله بركرفته از ر ساله دكترى نويسنده اول

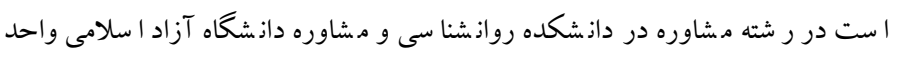

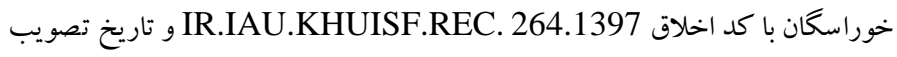

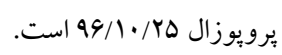
حامى مالى: اين يثزوهش در قالب رساله دكترى و بدون حمايت مالى مىباشد. نقش هر يكك از نويسند كان: نويسنده اول محقق اصلى اين يثزوهش است. نويسنده دوم و سوم استاد راهنما و نو يسنده جهارم استاد مشاور رساله مىباشند. تضاد منافع: نو يسند كان هيج تضاد منافعى در رابطه با اين يُزوهش اعلام نمىنمايند.

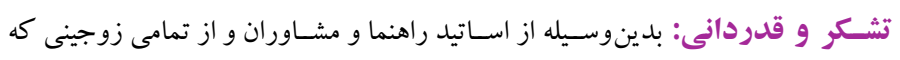

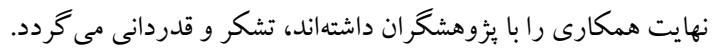

يُزوهش حاضر مانند ساير يُزوهشها داراى محدوديتهايى بود. اجراى

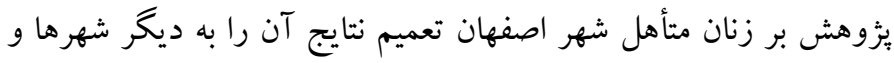

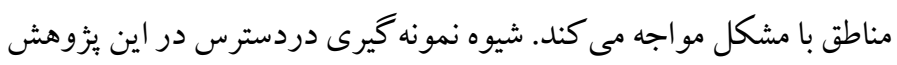
از محدوديتهاى ديخر تحقيق حاضر است كه بايد به آنها توجه كرد.

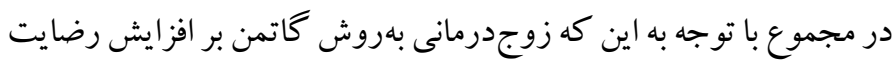

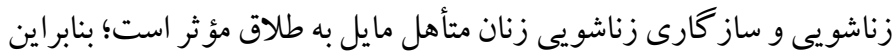

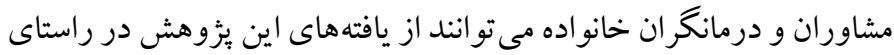

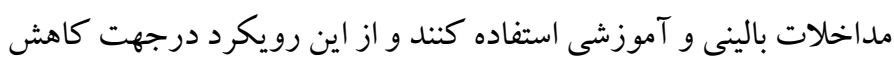
تعارضات زناشويى و بهبود روابط زوجين بهره برند. 


\section{References}

Alyson F., Shapiro., John M., Gottman. (2005). Effects on Marriage of a Psycho-CommunicativeEducationalIntervention With Couples Undergoingthe Transition to Parenthood, Evaluationat 1-Year Post Intervention, 5(1). 1-24. [Link]

Jafari A. (2017). Developing a psycho-educational package based on Satir,s model for conflicting couples and it,s effectiveness on reducing inefficient coping strategy and divorce probability. Quarterly of Counseling Culture and Psychotherapy, Allameh Tabataba'i University, 8, (30) (Persian). [Link]

Babcock JC., Gottman JM., Ryan KD., Gottman JS. (2013). A component analysis of a brief psychoeducational couples' workshop: one-year follow-up results,35(3). 252-80. [Link]

Cirhinlioglu FG., Tepe YK., Cirhinlioglu Z. (2017). Psychological distress, self esteem and emotional dependency of married individuals as predictors of marital adjustment. Proc Comp Sci,120. 164-71. [Link]

Danesh A. (1388). Increasing the marital compatibility of incompatible couples with counseling from an Islamic perspective. Journal of Psychological Studies, 6 (2) (Persian). [Link]

David P. (2015). Wedding the Gottman and Johnson Approaches into an Integrated Model of Couple Therapy, 23(4).336-45. [Link]

David P. Wedding the Gottman and Johnson Approaches into an Integrated Model of Couple Therapy. Fam J 2015;23(4):336-45. [Limk]

Dehghani sheshdeh Z., Yousefi Z. (2019). The Structural Equation Modeling of Desire to Divorce based on System, Psychological and Social Variables among High School Students' in Isfahan Mothers. Journal of Family Research, 15 (1). 155-171(Persian). [Link]

Funk J. L., Rogge R. D. (2007). Testing the ruler with item response theory: Increasing precision of measurement for relationship satisfaction with the Couples Satisfaction Index. Journal of Family Psychology, 21(4). 572-583. [Link]

Garanzini S., Yee A., Gottman J., Gottman J., Cole C., Preciado M., et al. (2017). Results of Gottman Method Couples Therapy with Gay and Lesbian Couples. Journal Marital Fam Ther, 43(4).674-84. [Link]
Gottman J., Swanson C., Swanson K. (2002). A General Systems Theory of Marriage: Nonlinear Difference Equation Modeling of Marital Interaction. Pers Soc Psychol Rev, 6(4). 326-40. [Link]

Gottman JM. (1994). What predicts divorce? The relationship between marital processes and marital outcomes. Hillsdale, NJ: Lawrence Erlbaum Associates. [Link]

Gottman J. M., Silver N. (2000). The seven principles for making marriage work. New York: Harmony Books. [Link]

Gottman John., Gottman, Julie. (2016). The Natural Principles of Love. Journal of Family Theory \& Review 9 (March 2017), 7-26 7. [Link]

Halford WK., Hayes S., Christensen A., Lambert M., Baucom DH., Atkins DC. (2012). Toward making progress feedback an effective common factor in couple therapy. Behav Ther,43(1).49-60. [Link]

Havasi N., Zahrakar K., MohsenZadeh F. (2017). A Study on the Efficacy of Gottman Marital Therapy as a Group Method in Reduction of Marital Burnout, 4(6) (Persian). [Link]

Hawkins MW., Carrère S., Gottman JM. (2002). Marital sentiment override: Does it influence couples' perceptions? Journal of Marriage and Family, 64(1).193-201. [Link]

Henderson A., Dunham S., Dermer S. (2013). Change, choice, and home: An integration of the work of Glasser and Gottman. Int $J$ Cho Theo Real Ther,32(2).36-47.

Johnson SA., Gottman's J. (2000). research on the behavioral differences between distressed and nondistressed couples. [Dissertation]. Salisbury State Unive, 78-79. [Link]

Karbalaie M., Azari E. (2017). Effectiveness of emotionfocused therapy in marital intimacy and in reducing marital burnout of couples visiting consultation centers in Tehran's second region. Journal of Psychology and Educational Sciences, 3(1-2),10817(Persian). [link]

Karimi A., Ahmadi P., Zahrakar K. (1399). The effectiveness of Gatman method of teaching marital skills on women's communication patterns. Quarterly Journal of Counseling and Psychotherapy Culture, Allameh Tabatabai University, 11 (44). 278-253 (Persian). [Link]

Mohammadi M., Zahrakar K., Jahangiri J., Davarniya R., Shakarami M., Morshedi M. (2017). [Assessing the efficiency of educational intervention based on Gottman's model on marital intimacy of women]. Journal Health, 8(1).74-84(Persian). [Link] 
Nilforoushan P., Navidian A. (2014). Composition of spouses' attachment dimensions on marital satisfaction. Journal of Fundamentals of Mental Health16(3). 200-12(Persian). [Link]

Ozguc S., Tanriverdi D. (2018). Relations Between Depression Level and Conflict Resolution Styles, Marital Adjustments of Patients With Major Depression and Their Spouses. Arch Psychiatr Nurs, 32(3).337-42. [Link]

Peterson-Post KM., Rhoades GK., Stanley SM., Markman HJ. (2014). Perceived criticism and marital adjustment predict depressive symptoms in a community sample. Behav Ther,45(4).564-75. [Link]

Spanier G. B. (1976). Measuring dyadic adjustment: New scale for assessing the quality of marriage and similar dyads. Journal of Marriage andFamily, 38. 15-28 [Link]

vafaei L., soleimaninan A A., mohammadzade ebrahimi A. (2020). The Effectiveness of "ForgivenessBased Group Counseling" on Post-divorce Women's Adjustment. JHPM, 9 (2).11-21. [Link]

Walker L. (2013). [Evaluating the impact of a Gottmanbased marriage strengthening program on families adopting children with special needs]. Florida Florida State University Libraries. [Link]

Walker L. K. (2013). Evaluating the Impact of a GottmanBased Marriage Strengthening Program on Families Adopting Children with Special Needs. Retrieved from. [Link]

Westerop K. Building healthy couple relationship: Do communication skills, gender, hope, and Xiong A, Gottman A, Park C, Baetens M, Pandza S, Matin A. (2000). The EmrR protein represses the Escherichia coli emrRAB multidrug resistance operon by directlybinding to its promoter region. Antimicrob Agents Chemother, 44(10).2905-7. [Link]

Yahyai E., Salimi H., Asgari M., Farahbakhsh, K. (2020). Develop a model for promoting marital satisfaction and evaluate its effectiveness In reducing the tendency to divorce. Scientific and cultural journal of women and family, 15 (53). 55-84 (Persian). [Link] 